\title{
TFAP2E Gene
}

National Cancer Institute

\section{Source}

National Cancer Institute. TFAP2E Gene. NCI Thesaurus. Code C117146.

This gene plays a role in the modification of gene expression. 